\title{
Timosaponin B-III exhibits antidepressive activity in a mouse model of postpartum depression by the regulation of inflammatory cytokines, BNDF signaling and synaptic plasticity
}

\author{
XIAO-LI ZHANG ${ }^{1 *}$, LIN WANG $^{2 *}$, LI XIONG $^{3}$, FENG-HUA HUANG ${ }^{4}$ and HAN XUE ${ }^{5}$ \\ ${ }^{1}$ Department of Ultrasonography, Zhongnan Hospital of Wuhan University; ${ }^{2}$ Department of Histology and \\ Embryology, Medical College of Wuhan University; Departments of ${ }^{3}$ Neurology, ${ }^{4}$ Obstetrics and Gynecology, \\ and ${ }^{5}$ Clinical Laboratory, Zhongnan Hospital of Wuhan University, Wuhan, Hubei 430071, P.R. China
}

Received April 29, 2016; Accepted May 11, 2017

DOI: $10.3892 / e t m .2017 .4930$

\begin{abstract}
The aim of this study was to investigate the antidepressive effects of timosaponin B-III (TB-III) and the underlying mechanism. A postpartum depression (PPD) mouse model was established by the administration of dexamethasone sodium phosphate during pregnancy. Mice with PPD were assigned to the following groups: Model, fluoxetine and high, medium and low doses of TB-III. Post-parturient mice without PPD served as a normal control group. To examine the effect of TB-III, mice were treated with TB-III, then forced swimming tests (FSTs) and tail suspension tests (TSTs) were performed to evaluate depression. Serum and hippocampal cytokines, namely tumor necrosis factor (TNF)- $\alpha$, interleukin (IL)-1 $\beta$, IL-6 and IL-10, were quantified using ELISAs and protein levels of hippocampal brain-derived neurotrophic factor (BDNF), glucagon synthase kinase (GSK)-3 $\beta$, glutamate receptor subunit 1 (GluR1), postsynaptic density protein 95 (PSD95) and synapsin I were quantified using western blot analysis. Compared with those in the control group, immobility time in the FST and TST, serum and hippocampal TNF- $\alpha$, IL-1 $\beta$ and IL-6 levels and hippocampal IL-10 levels were increased significantly in the model group $(\mathrm{P}<0.01)$. Serum IL-10 levels and hippocampal levels of BDNF, GSK-3 $\beta$, GluR1, PSD95 and synapsin I decreased significantly in the model group compared with the control group $(\mathrm{P}<0.01)$. Fluoxetine or TB-III $(10,20$ or $40 \mathrm{mg} / \mathrm{kg})$ treatment significantly decreased
\end{abstract}

Correspondence to: $\operatorname{Dr}$ Xiao-Li Zhang, Department of Ultrasonography, Zhongnan Hospital of Wuhan University, 169 Donghu Road, Wuhan, Hubei 430071, P.R. China

E-mail: xiaoliz_zhang@sina.com

*Contributed equally

Key words: depression, timosaponin B-III, forced swimming test, tail suspension test, inflammatory cytokines, bone-derived neurotrophic factor signaling pathway, synaptic plasticity immobility times in the FST and TST $(\mathrm{P}<0.01)$ and significantly reversed the aforementioned alterations in cytokine and protein levels $(\mathrm{P}<0.01)$. Thus, TB-III exhibited a protective effect against depression in PPD and such effects may have been mediated via the regulation of inflammatory cytokines, the BNDF signaling pathway and synaptic plasticity-related proteins.

\section{Introduction}

Postpartum depression (PPD) is a common mental disease (1), and an incidence of $10-15 \%$ has been indicated in the US, although this can be as high as $30 \%$ depending on the diagnostic criteria $(2,3)$. Depression prior to pregnancy is one of the greatest risk factors for PPD (4). Psychological and physiological factors are major etiologies for PPD development (5). Psychological factors primarily include anxiety during pregnancy and personality characteristics, while physiological factors include genetic and physical factors, hormone level and the delivery process (6-8). Currently, drug therapies and psychotherapy are the two most commonly used treatments for PPD, and combined therapy is reported to be more effective than either treatment alone $(9,10)$. However, the success rate of treatment is low and the effects are not satisfactory. Therefore, the exploration of new treatments against PPD is critical.

Timosaponin B-III (TB-III) is a saponin isolated from Anemarrhenae rhizome, the dry rhizome of Anemarrhena asphodeloides Bge. (Liliaceae). Although it has been reported to exhibit antidepressive effects on behavior, including immobility time in forced swimming tests (FSTs) and tail suspension tests (TSTs), horizontal locomotion, and frequencies of rearing, grooming and defecation in an open-field test (11), the underlying mechanisms of TB-III remain unclear.

In the current study, a PPD model was established in mice and the antidepressive effects of TB-III were evaluated. Furthermore, certain pro-inflammatory cytokines, brain-derived neurotrophic factor (BDNF) signaling molecules and synaptic plasticity-related proteins were evaluated, and it was found that TB-III reverses alterations in the levels of these molecules in PPD model mice. This indicated that 
the antidepressive effects of TB-III may be mediated through the regulation of inflammatory cytokines, the BNDF signaling pathway and synaptic plasticity-relevant proteins. The current results provide a theoretical basis for the treatment of PPD with TB-III in clinical practice.

\section{Materials and methods}

Plant material. Anemarrhenae rhizome was purchased from Chengdu Chinese Herbal Medicine Market (Chengdu, China) in 2014 and identified by Dr Lin Wang. A voucher specimen (no. MCWHU201479) was stored in the Medical College of Wuhan University (Wuhan, China) for future reference.

Chemicals and reagents. Analytical grade chloroform, methanol, ethanol and silica gel (200-300 mesh) were obtained from Qingdao Haiyang Chemical Co., Ltd. (Qingdao, China). High performance liquid chromatography (HPLC) grade acetonitrile was purchased from Thermo Fisher Scientific, Inc. (Waltham, MA, USA). HPLC grade water was prepared using the Milli-Q Advantage A10 water purification system (EMD Millipore, Billerica, MA, USA). Fluoxetine and dexamethasone sodium phosphate were obtained from Eli Lilly and Co., Ltd. (Indianapolis, IN, USA) and Guangzhou Tianxin Pharmaceutical Co., Ltd. (Guangzhou, China), respectively. Tumor necrosis factor (TNF)- $\alpha$, interleukin (IL)-1 $\beta$, IL-6 and IL-10 ELISA kits (MTA00B, MLB00C, M6000B and M1000B, respectively) were purchased from R\&D Systems China Co., Ltd. (Shanghai, China). Enhanced Bicinchoninic Acid (BCA) Protein Assay kit was purchased from Beyotime Institute of Biotechnology (Shanghai, China). Polyvinylidene fluoride (PVDF) membranes were purchased from Merck KGaA (Darmstadt, Germany). Primary antibodies for BDNF (ab108319), glycogen synthase kinase (GSK)-3ß (ab32391), glutamate receptor subunit 1 (GluR1, ab31232) were obtained from Abcam (Cambridge, UK). Primary antibodies for postsynaptic density protein 95 (PSD95; 2507), and synapsin I (5297) and $\beta$-actin (970) were purchased from Abcam and Cell Signaling Technology, Inc. (Danvers, MA, USA). Horseradish peroxidase (HRP)-conjugated anti-rabbit antibody (111-035-144) was obtained from Jackson ImmunoResearch Laboratories, Inc. (West Grove, PA, USA).

Animals. A total of 100 adult BALB/c female mice (3-5 months old; 18-22 g) were purchased from the Animal Research Center of Wuhan University (Wuhan, China) and housed in a temperature-controlled vivarium $\left(25^{\circ} \mathrm{C}\right)$ with relative humidity of $65 \%$ and a 12-h light/dark cycle. All mice received water and food ad libitum. All animal treatments were conducted in strict accordance with the National Institutes of Health Guide for Care and Use of Laboratory Animals (12). The study was performed with the approval of the ethics committee of the Medical College of Wuhan University (protocol no. MCWHUEC2015038).

Preparation of TB-III. Anemarrhenae rhizome (10 kg) was finely ground and extracted three times with water. The water solvent was combined and centrifuged at $1,500 \mathrm{x} g$ for $10 \mathrm{~min}$ at $4^{\circ} \mathrm{C}$. The supernatant was added to an AB- 8 macroporous resin-containing chromatography column, and eluted with 0 ,
30, 40 and 50\% ethanol successively (13). The 50\% ethanol extract was concentrated under vacuum and subjected to column chromatography over silica gel (200-300 mesh), with elution using chloroform-methanol (10:1, 8:1, 6:1, 3:1 and 1:1, $\mathrm{v} / \mathrm{v})$. The eluate was collected per $500 \mathrm{ml}$ as one fraction, and 12 fractions were obtained. Fractions 5-10, which were chosen due to their known optimal effect, were subjected to preparative HPLC (Agilent 1260; Agilent Technologies, Inc., Santa Clara, CA, USA), eluted with acetonitrile-water (1:1, $\mathrm{v} / \mathrm{v})$ and served as TB-III $(1,024 \mathrm{mg})$ in the current study. A SHIMADZU LC-20AT chromatographer equipped with dual pumps, SPD-20 UV detector and 7725i manual sample injector was used, together with a guard column $(4.0 \times 3.0 \mathrm{~mm}$; $5 \mu \mathrm{m}$; Phenomenex Inc., Torrance, CA, USA). The temperature was set at $30^{\circ} \mathrm{C}$, the wavelength was set at $336 \mathrm{n}$, and the flow rate was $0.8 \mathrm{ml} / \mathrm{min}$. The purity of TB-III was $97.5 \%$, verified by area normalization method of HPLC (14), and its chemical structure (Fig. 1) was identified by comparison of its proton nuclear magnetic resonance (NMR) and carbon-13 NMR data (Varian Mercury-400; Varian Medical Systems, Palo Alto, CA, USA) with those in previous literature $(15,16)$.

Establishment of a PPD model. A PPD mouse model was established according to a previously published method with some modification (17). Copulation of mice was performed in a cage with a male mouse and a female mouse. At $24 \mathrm{~h}$ following the placement of the mice in the copulation cage, a vaginal smear was performed to detect whether the female mice were pregnant. From day 1 after pregnancy, mice were injected subcutaneously with normal saline at a dose of $1 \mathrm{ml} / \mathrm{kg}$ once a day for 14 days, then injected subcutaneously with dexamethasone sodium phosphate at a dose of $0.2 \mathrm{mg} / \mathrm{kg}$ once a day until birth of offspring ( 7 days). Then, forced swim test (FST) or tail suspension test (TST) were used to evaluate whether the PPD model had been successfully established. A total of 10 pregnant mice were injected subcutaneously with normal saline at a dose of $1 \mathrm{ml} / \mathrm{kg}$ once a day throughout pregnancy as the normal control group.

FST for mice. The FST was performed at $24 \mathrm{~h}$ following the final drug treatment according to a previously described method, with minor modifications $(18,19)$. Briefly, the mice were individually placed in a glass cylinder $(19 \mathrm{~cm}$ in diameter and $30 \mathrm{~cm}$ in height) containing $18-\mathrm{cm}$-deep water at $20 \pm 2^{\circ} \mathrm{C}$ and recorded by video camera. The immobility time was calculated during the last 4 min of the 6-min test using a ZH-QPT analytic system (Huaibei Zhenghua Bioinstrumentation Co., Ltd., Huaibei, China), and the immobility time was recorded in sec. The recorded tapes were separately evaluated by 2 observers who were blinded to the actual treatment. Immobility was defined as the time the mouse spent floating in the water without struggling or only making those movements required to keep its head above the water. Conventional antidepressant drugs can decrease the immobility time in this test (20).

Tail suspension test. The TST was performed according to a previously described method, with minor modifications (21). Briefly, the mice were individually suspended in a box $(25 \times 25 \times 30 \mathrm{~cm})$ by its tail using adhesive tape $(1 \mathrm{~cm}$ from the end), with the head $15 \mathrm{~cm}$ above the bottom. The tests were 


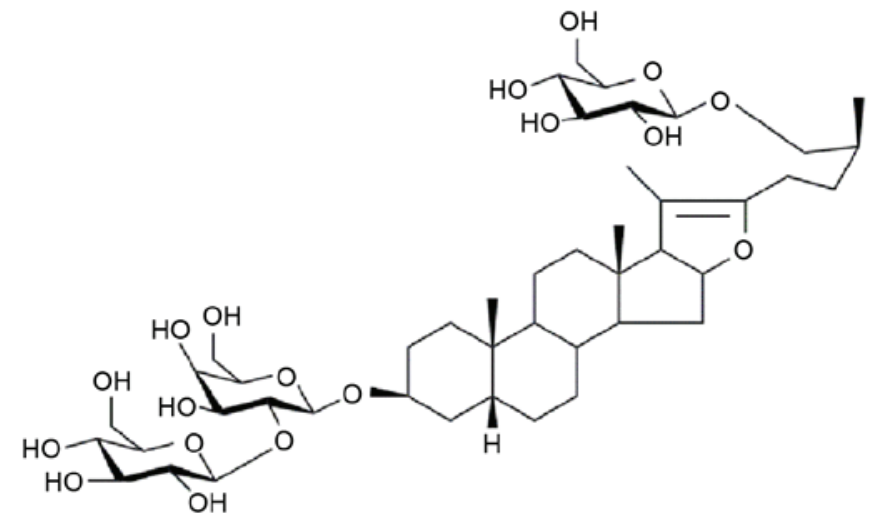

Figure 1. Chemical structure of timosaponin B-III.

performed in a darkened room with minimal background noise and the mice were separated from each other to prevent visual and acoustic interferences. Each mouse was recorded using a video camera. The immobility time was calculated during the last $4 \mathrm{~min}$ of the 6 -min test and was reported in sec. The recorded tapes were separately evaluated by 2 observers who were blinded to the actual treatment. Immobility was defined only when the mouse hung passively and was completely motionless. Conventional antidepressant drugs had the ability to decrease the immobility time in this test, which is a phenomenon that has been described previously (21).

Grouping and drug administration. Post-parturient mice with PPD were randomly divided into five groups $(n=10$ in each group): Model, fluoxetine, and high, medium and low dose TB-III groups. Mice in the model and normal groups were orally administered vehicle $[0.5 \%$ sodium carboxymethyl cellulose (CMC-Na; WEALTHY; Shanghai)] once a day for 7 days. Mice in the fluoxetine group were treated orally with $10 \mathrm{mg} / \mathrm{kg}$ fluoxetine once a day for 7 days. Mice in the high, medium and low dose TB-III groups were treated orally with 40, 20 and $10 \mathrm{mg} / \mathrm{kg}$ TB-III, respectively, once a day for 7 days. Fluoxetine and TB-III were dissolved in 0.5\% CMC-Na to different concentrations such that all mice received an intragastric volume of $10 \mathrm{ml} / \mathrm{kg}$.

Quantification of inflammatory cytokines. Following the FST and TST, mice were anesthetized with $10 \%$ chloral hydrate (30 $\mathrm{mg} / \mathrm{kg}$ ), and blood samples were obtained from the abdominal aorta. Following incubation at room temperature for $2 \mathrm{~h}$, A 30-ml portion of the homogenate was mixed with $100 \mathrm{ml}$ of normal saline and then centrifuged at $1,500 \mathrm{x} \mathrm{g}$ for $15 \mathrm{~min}$ at $4^{\circ} \mathrm{C}$ to obtain serum, which was then frozen at $-20^{\circ} \mathrm{C}$. Subsequently, mice were sacrificed by decapitation, and their hippocampal tissues were dissected and frozen in liquid nitrogen. Hippocampal tissues were weighed, cut into pieces $\left(\sim 1 \mathrm{~mm}^{3}\right)$. Supernatants from homogenates were used for determination. The homogenate was prepared into $10 \%$ homogenate with Ultrasonic cell disintegrator (Shanghai Bilon Instrument Co., Ltd., Shanghai, China) and centrifuged at $1500 \mathrm{x} \mathrm{g}$ for $15 \mathrm{~min}$ at $4^{\circ} \mathrm{C}$ before the supernatant was frozen at $-20^{\circ} \mathrm{C}$. Blood serum and the supernatant from hippocampal tissues were used to determine the levels of pro-inflammatory
(TNF- $\alpha$, IL-1 $\beta$ and IL-6) and anti-inflammatory (IL-10) cytokines with ELISA kits, following the manufacturer's protocols. Absorbance was determined at $450 \mathrm{~nm}$ with a 680 Microplate Reader (Bio-Rad Laboratories, Inc., Hercules, CA, USA). The concentration of each inflammatory cytokine was calculated using standard curves.

Western blot analysis. Following pretreatment with liquid nitrogen, these tissues were cut into pieces and centrifuged at $1,611 \mathrm{x} \mathrm{g}$ for $30 \mathrm{~min}$ at $4^{\circ} \mathrm{C}$, and the process is repeated for 3-5 times. Radioimmunoprecipitation lysis buffer, phenyl methane sulfonyl fluorideand phosphatase inhibitor (Beyotime, Shanghai, China) were added, and the tissues were ultrasonicated, resting for $30 \mathrm{~min}$ at $4^{\circ} \mathrm{C}$. The tissues were further centrifuged at $1,611 \mathrm{xg}$ at $4^{\circ} \mathrm{C}$ for $30 \mathrm{~min}$, and the supernatant was removed. Total protein of the hippocampal tissue was extracted and quantified using an Enhanced BCA Protein Assay kit. Equal amounts of total protein (35 $\mu \mathrm{g}$ per lane) were separated by $10 \%$ SDS-PAGE and blotted onto PVDF membranes. After blocking with 5\% non-fat milk, PVDF membranes were incubated with primary antibodies for $\beta$-actin (1:500), BDNF (1:500), GSK-3 $\beta$ (1:200), GluR1 (1:500), PSD95 (1:100) and synapsin I (1:100) overnight at $4^{\circ} \mathrm{C}$. Following washing with Tris-buffered saline with Tween-20 (TBS-T), polyvinylidene difluoride membranes were incubated with HRP-conjugated anti-rabbit antibody $(1: 5,000)$ in TBS-T at room temperature for $2 \mathrm{~h}$. PVDF membranes were then washed with TBS-T, and proteins were visualized by enhanced chemiluminescence (1-800-424-6723; Bio-Rad Laboratories, Inc.). $\beta$-actin was used as a loading control. The levels of proteins were calculated as grayscale using ImageJ 1.48 (National Institutes of Health; Bethesda, MD, USA) and normalized relative to $\beta$-actin. A total of 3 biological replicates were performed for statistical analysis.

Statistical analysis. All data are presented as the mean \pm standard deviation. Differences among different groups were analyzed with one-way analysis of variance followed by Fisher's least significant difference post hoc test. All analyses were conducted using SPSS 19.0 (IBM Corp., Armonk, NY, USA). $\mathrm{P}<0.05$ was considered to indicate a statistically significant difference.

\section{Results}

TB-III has antidepressive effects in the FST and TST. As shown in Table I, the immobility time of the model group was significantly increased in the FST and TST compared with the normal control group $(\mathrm{P}<0.01)$, indicating successful establishment of the PPD model. Following treatment with fluoxetine or TB-III $(10,20$ or $40 \mathrm{mg} / \mathrm{kg})$, the immobility time in the FST and TST was reduced significantly $(\mathrm{P}<0.01)$ compared with the model group. A dose of $40 \mathrm{mg} / \mathrm{kg}$ TB-III exhibited similar results to fluoxetine treatment. Thus, TB-III was indicated to have antidepressive effects against PPD.

$T B$-III reduces the alteration of inflammatory cytokine levels in mice with PPD. To explore the possible mechanism underlying the antidepressive effect of TB-III, the effect of TB-III on inflammatory cytokines in serum and hippocampal tissues was 
Table I. Immobility time of mice with postpartum depression in the FST and TST.

\begin{tabular}{lccc}
\hline & & \multicolumn{2}{c}{ Immobility time (sec) } \\
\cline { 3 - 4 } Group & Dose $(\mathrm{mg} / \mathrm{kg})$ & FST & TST \\
\hline Normal & - & $32.4 \pm 6.5$ & $42.1 \pm 7.3$ \\
Model & - & $158.4 \pm 13.8^{\mathrm{a}}$ & $138.2 \pm 14.5^{\mathrm{a}}$ \\
Fluoxetine & 10 & $58.9 \pm 5.1^{\mathrm{b}}$ & $42.1 \pm 6.3^{\mathrm{b}}$ \\
TB-III & 10 & $108.7 \pm 11.3^{\mathrm{b}}$ & $98.7 \pm 8.6^{\mathrm{b}}$ \\
TB-III & 20 & $84.2 \pm 8.9^{\mathrm{b}}$ & $74.3 \pm 9.3^{\mathrm{b}}$ \\
TB-III & 40 & $62.1 \pm 9.5^{\mathrm{b}}$ & $53.4 \pm 8.1^{\mathrm{b}}$ \\
\hline
\end{tabular}

${ }^{\mathrm{a}} \mathrm{P}<0.01$ vs. the normal group; ${ }^{\mathrm{b}} \mathrm{P}<0.01$ vs. the model group. TB-III, timosaponin B-III; FST, forced swimming test; TST, tail suspension test.

evaluated. Compared with those in the normal group, TNF- $\alpha$, IL-1 $\beta$ and IL-6 levels in the serum (Table II) and hippocampal tissue (Table III) were significantly increased in the model group $(\mathrm{P}<0.01)$. IL-10 levels were significantly decreased in the serum (Table I) and significantly increased in the hippocampal tissue (Table II) of the model group compared with the control $(\mathrm{P}<0.01)$. Fluoxetine or TB-III $(10,20$ or $40 \mathrm{mg} / \mathrm{kg})$ treatment significantly reversed the up- or downregulation induced in the model group $(\mathrm{P}<0.01$; Tables II and III). Thus, the antidepressive effect of TB-III may be executed through the regulation of inflammatory cytokines.

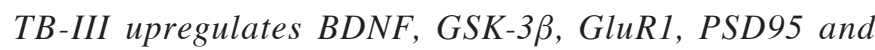
Synapsin I protein levels in the hippocampal tissue of mice with PPD. As shown in Fig. 2, BDNF, GSK-3 $\beta$, GluR1, PSD95 and synapsin I proteins in the hippocampal tissue of the model group were decreased significantly compared with those in the control group $(\mathrm{P}<0.01)$. This indicated that cognitive dysfunction may result from alterations in BDNF signaling, synaptic plasticity-relevant proteins and associated neural functions. Compared with the model group, fluoxetine or TB-III (10, 20 or $40 \mathrm{mg} / \mathrm{kg}$ ) treatment significantly increased BDNF, GSK-3 $\beta$, GluR1, PSD95 and synapsin I protein expression in hippocampal tissue $(\mathrm{P}<0.01$; Fig. 2;). Thus, the antidepressive effect of TB-III may be executed through the rescue of BDNF signaling and synaptic plasticity.

\section{Discussion}

In the present study, the antidepressive activity and mechanism of TB-III was evaluated in a mouse model of PPD by monitoring the immobility time in a FST and TST, determining inflammatory cytokine levels in serum and hippocampal tissue, and detecting BDNF, GSK-3 $\beta$, GluR1, PSD95 and synapsin I protein levels in hippocampal tissue. The results demonstrated that TB-III exhibited protective activity against depression in PPD mice, and indicated that inflammatory cytokines, BNDF signaling and synaptic plasticity may be involved in such effects.

Fluoxetine is an antidepressive drug, and was used as a positive control for drug administration in the present study, as a comparator for TB-III (22). The FST and TST are well-established models for the assessment of depression in animal models (23). In these behavioral tests, TB-III reduced the immobility time of mice with PPD, with a dose of $40 \mathrm{mg} / \mathrm{kg}$ TB-III exhibiting results comparable to those of fluoxetine treatment, suggesting that TB-III is a potent antidepressant against PPD.

Previous results indicate that inflammatory signaling plays an important role in the pathophysiology of depression and that pro-inflammatory cytokine levels are abnormally high in depressed patients $(24,25)$. The current results were consistent with this notion and supported the behavioral abnormities to further validate the successful establishment of the PPD model in mice. In line with the antidepressive effect on behavior, TB-III treatment suppressed the increased inflammatory responses of mice with PPD in the present study. TB-III reversed the increases in pro-inflammatory cytokine (TNF- $\alpha$, IL-1 $\beta$ and IL-6) levels in the serum and hippocampal tissue in PPD mice. However, the reduction of hippocampal IL-10 in PPD mice could be level in hippocampal tissue was alleviated by TB-III. Such differences in increase/decrease of various inflammatory factors may result from the compensatory effect of body (26) and various inflammatory factors may influence the brain via different signaling mechanisms and different cell types. Therefore, the regulation of inflammatory cytokine levels in the serum and hippocampal tissue of mice with PPD is another possible mechanism for the antidepressive effect of TB-III.

Proteins associated with neural function may also be important for the development and/or treatment of depression. BNDF plays an important role in depression and direct hippocampal BNDF infusions have been shown to produce antidepressive effects in rodents (27); thus, antidepressants may exert therapeutic effects by increasing BDNF levels (28). GSK-3 $\beta$ demonstrated antidepressive activity in a chronic unpredictable stress model of depression (29). Synaptic plasticity, for which GluR1, PSD95 and synapsin I are required for maintenance (30), plays an important role in the pathophysiology of depression; thus, antidepressants may also exert therapeutic effects by regulating synaptic plasticity-related signaling (31). Consistent with these three notions, the current results indicated that BDNF, GSK-3 $\beta$, GluR1, PSD95 and synapsin I protein levels in hippocampal tissue were downregulated in PPD mice compared with the controls, while TB-III treatment upregulated these factors. This suggested that activation of the BNDF signaling pathway and maintenance of synaptic plasticity may also be involved in the antidepressive effect of TB-III. However, due to technical limitations, the association between these tested factors (BDNF, GSK-3 $\beta$, GluR1, PSD95) and the antidepressive effect of TB-III has not been fully determined. Therefore, future studies are required to investigate whether these factors have any sufficient antidepressive effects or necessary role in the pathophysiology of depression.

In conclusion, TB-III exhibited protective activity against depression in a mouse model of PPD, and the mechanisms of its activity may involve the regulation of inflammatory cytokines, BNDF signaling and synaptic plasticity. Thus, TB-III may serve as an antidepressant against PPD. 
Table II. Effect of TB-III on TNF- $\alpha$, IL- $\beta$, IL-6 and IL-10 levels in the serum of mice with postpartum depression.

\begin{tabular}{|c|c|c|c|c|c|}
\hline Group & Dose (mg/kg) & TNF- $\alpha(p g / m l)$ & $\mathrm{IL}-\beta(\mathrm{pg} / \mathrm{ml})$ & IL-6 (pg/ml) & IL-10 (pg/ml) \\
\hline Normal & - & $63.1 \pm 2.8$ & $58.4 \pm 2.4$ & $42.1 \pm 1.7$ & $321.7 \pm 10.2$ \\
\hline Model & - & $165.3 \pm 6.4^{\mathrm{a}}$ & $138.7 \pm 5.8^{\mathrm{a}}$ & $153.4 \pm 4.9^{\mathrm{a}}$ & $107.5 \pm 6.9^{\mathrm{a}}$ \\
\hline Fluoxetine & 10 & $85.3 \pm 3.5^{\mathrm{b}}$ & $76.3 \pm 3.2^{b}$ & $65.2 \pm 3.7^{\mathrm{b}}$ & $221.4 \pm 12.3^{\mathrm{b}}$ \\
\hline TB-III & 10 & $142.4 \pm 5.3^{b}$ & $117.2 \pm 4.1^{\mathrm{b}}$ & $99.4 \pm 4.1^{\mathrm{b}}$ & $127.1 \pm 7.8^{b}$ \\
\hline TB-III & 20 & $112.3 \pm 4.2^{b}$ & $104.7 \pm 3.8^{b}$ & $90.7 \pm 2.6^{\mathrm{b}}$ & $153.4 \pm 10.6^{\mathrm{b}}$ \\
\hline TB-III & 40 & $98.1 \pm 2.3^{\mathrm{b}}$ & $85.2 \pm 2.7^{\mathrm{b}}$ & $84.3 \pm 3.1^{\mathrm{b}}$ & $180.7 \pm 8.1^{b}$ \\
\hline
\end{tabular}

${ }^{\text {aP }}<0.01$ vs. the normal group; ${ }^{\text {}} \mathrm{P}<0.01$ vs. the model group. TB-III, timosaponin B-III; TNF, tumor necrosis factor; IL, interleukin.

Table III. Effect of TB-III on TNF- $\alpha$, IL- $\beta$, IL-6 and IL-10 levels in the hippocampal tissues of mice with postpartum depression.

\begin{tabular}{|c|c|c|c|c|c|}
\hline Group & Dose (mg/kg) & TNF- $\alpha(\mathrm{pg} / \mathrm{ml})$ & $\mathrm{IL}-\beta(\mathrm{pg} / \mathrm{ml})$ & IL-6 (pg/ml) & IL-10 (pg/ml) \\
\hline Normal & - & $59.3 \pm 2.1$ & $8.7 \pm 0.7$ & $92.3 \pm 2.4$ & $132.4 \pm 8.1$ \\
\hline Model & - & $95.2 \pm 3.3^{\mathrm{a}}$ & $13.4 \pm 1.2^{\mathrm{a}}$ & $135.8 \pm 3.5^{\mathrm{a}}$ & $231.3 \pm 10.2^{\mathrm{a}}$ \\
\hline Fluoxetine & 10 & $65.3 \pm 2.6^{\mathrm{b}}$ & $7.1 \pm 0.8^{\mathrm{b}}$ & $71.4 \pm 3.2^{b}$ & $149.7 \pm 7.1^{\mathrm{b}}$ \\
\hline TB-III & 10 & $82.5 \pm 2.4^{\mathrm{b}}$ & $11.2 \pm 0.9^{\mathrm{b}}$ & $93.5 \pm 4.3^{b}$ & $196.5 \pm 9.8^{b}$ \\
\hline TB-III & 20 & $76.1 \pm 2.0^{\mathrm{b}}$ & $9.3 \pm 0.7^{b}$ & $85.3 \pm 2.2^{b}$ & $174.2 \pm 11.3^{\mathrm{b}}$ \\
\hline TB-III & 40 & $68.7 \pm 3.5^{\mathrm{b}}$ & $8.1 \pm 0.8^{\mathrm{b}}$ & $78.4 \pm 3.0^{\mathrm{b}}$ & $156.3 \pm 8.4^{\mathrm{b}}$ \\
\hline
\end{tabular}

${ }^{\mathrm{a}} \mathrm{P}<0.01$ vs. the normal group; ${ }^{\mathrm{b}} \mathrm{P}<0.01$ vs. the model group. TB-III, timosaponin B-III; TNF, tumor necrosis factor; IL, interleukin.
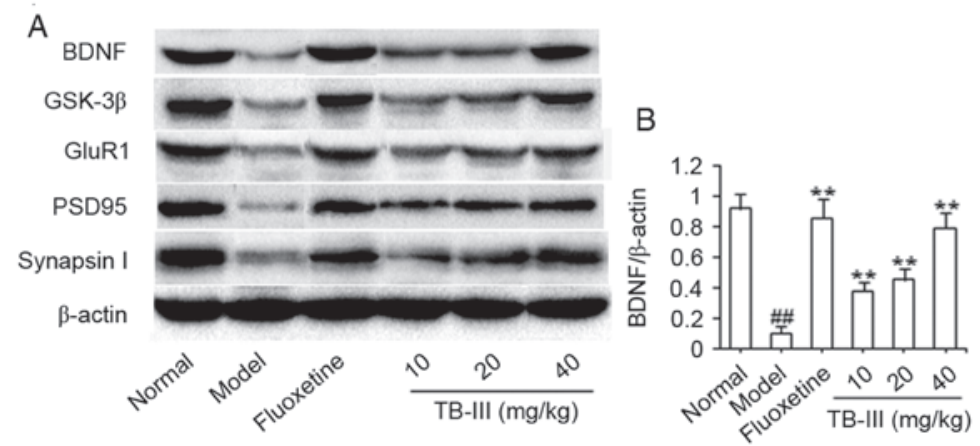

C
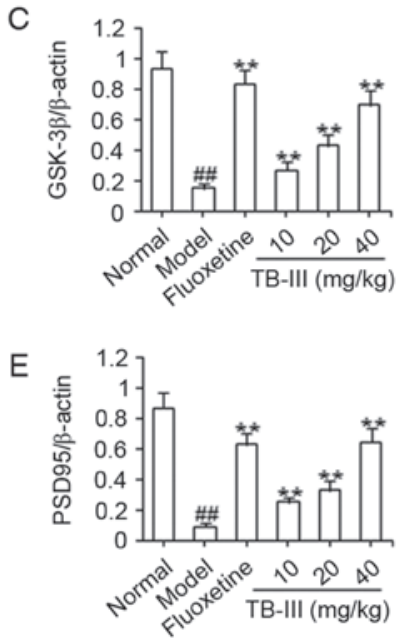

D
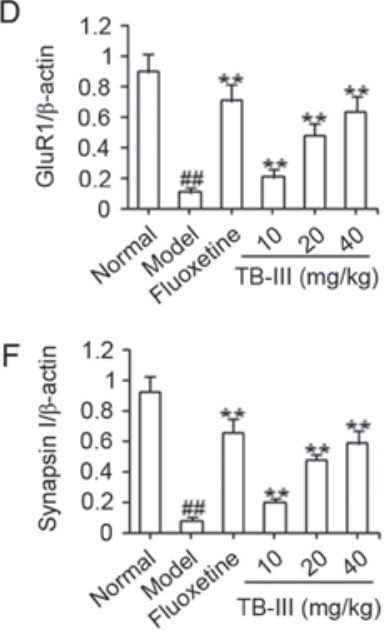

Figure 2. Effect of TB-III on synaptic protein levels in PPD mice. (A) Sample western blots and (B-F) quantified data indicate the effect of TB-III on synaptic

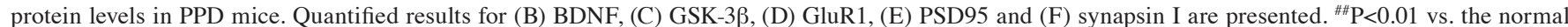
group; ${ }^{* *} \mathrm{P}<0.01$ vs. the model group. TB-III, timosaponin B-III; BDNF, brain-derived neurotrophic factor; GSK-3 $\beta$, glucagon synthase kinase-3 $\beta$; GluR1, glutamate receptor subunit 1; PSD95, postsynaptic density protein 95; PPD, postpartum depression. 


\section{References}

1. O'Hara MW and McCabe JE: Postpartum depression: Current status and future directions. Annu Rev Clin Psychol 9: 379-407, 2013.

2. Darcy JM, Grzywacz JG, Stephens RL, Leng I, Clinch CR and Arcury TA: Maternal depressive symptomatology: 16-month follow-up of infant and maternal health-related quality of life. J Am Board Fam Med 24: 249-257, 2011.

3. Vesga-López O, Blanco C, Keyes K, Olfson M, Grant BF and Hansin DS: Psychiatric disorders in pregnant and postpartum women in the United States. Arch Gen Psychiatry 65: 805-815, 2008.

4. O'Hara MW: Postpartum depression: What we know. J Clin Psychol 65: 1258-1269, 2009.

5. O'Hara and Michael W (eds): Postpartum depression: Causes and consequences. Springer-Verlag, New York, NY, 1995.

6. Brummelte S and Galea LA: Postpartum depression: Etiology, treatment and consequences for maternal care. Horm Behav 77: $153-166,2016$

7. Bloch M, Daly RC and Rubinow DR: Endocrine factors in the etiology of postpartum depression. Compr Psychiatry 44: 234-246, 2003.

8. Beck CT: A meta-analysis of predictors of postpartum depression. Nurs Res 45: 297-303, 1996.

9. Cui LL, Wang DN, Mao PX, Ren YP and Tang YL: Evaluation and treatment for postpartum depression. J Int Reprod Health/Fam Plan 34: 169-172, 2015.

10. Wisner KL, Parry BL and Piontek CM: Clinical practice. Postpartum depression. N Eng J Med 347: 194-199, 2002.

11. Jiang W, Guo J, Xue R, Zhu K, Li Z, Chen M and Huang C: Anti-depressive activities and biotrasformation of timosaponin B-III and its derivatives. Nat Prod Res 28: 1446-1453, 2014.

12. The National Research Council of The National Academy of Sciences: Guide for the Care and Use of Laboratory Animals. 8th edition. The National Academies Press, Washington, DC, 2010.

13. Wang P, Sun H, Liu D, Jiao Z, Yue S, He X, Xia W, Ji J and Xiang L: Protective effect of a phenolic extract containing indoline amides from Portulaca oleracea against cognitive impairment in senescent mice induced by large dose of D-galactose /NaNO (2). J Ethnopharmacol 203: 252-259, 2017.

14. Jiao ZZ, Wang HN, Wang PP, Sun HX, Yue S and Xiang L: Detection and quantification of cyclo-dopa amides in Portulace oleracea L. by HPLC-DAD and HPLC-ESI-MS/MS. J Chin Pharm Sci 23: 533-542, 2014

15. Bian J, Xu SS, Huang S and Wang ZX: A study on the chemical constituents of Anemarrhena aspphodeloides Bge. J Shenyang Pharmaceut Univ 13: 34-40, 1996.

16. Peng Y, Zhang YJ, Ma ZQ, Pan WS, Sun YQ and Song SJ: Two new saponins from Anemarrhena asphodeloides Bge. Chin Chemi Lett 18: 171-174, 2007.
17. Wan XY, Zhang TZ, Huang KK, Huang ZH, Wang XP and Jiang D: Postpartum depression animal model in rats and its behavior study. J Trop Med 13: 385-389, 2013.

18. Detke MJ, Rickels M and Lucki I. Active behaviors in the rat forced swimming test differentially produced by serotonergic and noradrenergic antidepressants. Psychopharmacology 121: 66-72, 1995.

19. Porsolt RD, Bertin A and Jalfre M: Behavioral despair in mice: A primary screening test for antidepressants. Arch Int Pharmacodyn Ther 229: 327-336, 1977.

20. Szopa A, Poleszak E, Wyska E, Serefko A, Wośko S, Wlaź A, Pieróg M, Wróbel A and Wlaź P: Caffeine enhances the antidepressant-like activity of common antidepressant drugs in the forced swim test in mice. Naunyn Schmiedebergs Arch Pharmacol 389: 211-221, 2016.

21. van der Heyden JA, Molewijk E and Olivier B: Strain differences in response to drugs in the tail suspension test for antidepressant activity. Psychopharmacology (Berl) 92: 127-130, 1987.

22. Volz HP and Laux P: Potential treatment for subthreshold and mild depression: A comparison of St. John's wort extracts and fluoxetine. Compr Psychiatry 41 (2 Suppl 1): S133-S137, 2000.

23. Wang W, Hu X, Zhao Z, Liu P, Hu Y, Zhou J, Zhou D, Wang Z, Guo D and Guo H: Antidepressant-like effects of liquiritin and isoliquiritin from Glycyrrhiza uralensis in the forced swimming test and tail suspension test in mice. Prog Neuropsychopharmacol Biol Psychiatry 32: 1179-1184, 2008.

24. Raison CL, Capuron L and Miller AH: Cytokines sing the blues: Inflammation and the pathogenesis of depression. Trends Immunol 27: 24-31, 2006

25. Felger JC and Lotrich FE: Inflammatory cytokines in depression: Neurobiological mechanisms and therapeutic implications. Neuroscience 246: 199-229, 2013.

26. Zhao Y, Xia C, Bao Y, Hao L, Xu Y, Wang XY, Gao Q, Gu HF and Zhang ZX: The effect of Ginkgo biloba extract 50 on behavior and inflammatory cytokines levels in depressed rats. Pharm Clinof Chin Mat Med 31: 88-92, 2015.

27. Siuciak JA, Lewis DR, Wiegand SJ and Lindsay RM: Antidepressant-like effect of brain-derived neurotrophic factor (BDNF). Pharmacol Biochem Behav 56: 131-137, 1997.

28. Martinowich K, Manji H and Lu B: New insights into BDNF function in depression and anxiety. Nat Neurosci 10: 1089-1093, 2007.

29. Garza JC, Guo M, Zhang W and Lu XY: Leptin restores adult hippocampal neurogenesis in a chronic unpredictable stress model of depression and reverses glucocorticoid-induced inhibition of

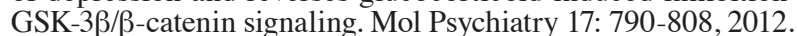

30. Duman RS: Pathophysiology of depression: The concept of synaptic plasticity. Eur Psychiatry 17 (Suppl 3): S306-S310, 2002.

31. Colbran RJ and Brown AM: Calcium/calmodulin-dependent protein kinase II and synaptic plasticity. Curr Opin Neurobiol 14: 318-327, 2004. 